\title{
Recurrent viral infections associated with a homozygous CORO1A mutation that disrupts oligomerization and cytoskeletal association
}

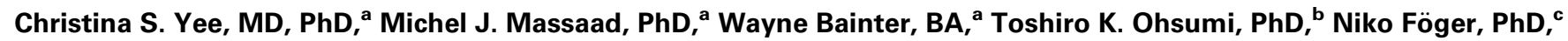
Andrew C. Chan, MD, PhD, ${ }^{d}$ Nurten A. Akarsu, MD, ${ }^{e}$ Caner Aytekin, MD, ${ }^{f}$ Deniz Çagdas Ayvaz, MD, PhD, ${ }^{9}$ Ilhan Tezcan, MD, PhD, ${ }^{\mathbf{9}}$ Özden Sanal, MD, ${ }^{\mathbf{9}}{ }^{*}$ Raif S. Geha, MD, ${ }^{\mathbf{a}}$ and Janet Chou, MD ${ }^{\mathbf{a} *}$ Boston, Mass, Hannover, Germany, San Francisco, Calif, and Ankara, Turkey

Background: Coronin-1A (CORO1A) is a regulator of actin dynamics important for T-cell homeostasis. CORO1A deficiency causes $\mathbf{T}^{-} \mathbf{B}^{+}$natural killer-positive severe combined immunodeficiency or T-cell lymphopenia with severe viral infections. However, because all known human mutations in CORO1A abrogate protein expression, the role of the protein's functional domains in host immunity is unknown.

Objective: We sought to identify the cause of the primary immunodeficiency in 2 young adult siblings with a history of

\footnotetext{
From athe Division of Immunology, Boston Children's Hospital and Department of Pediatrics, Harvard Medical School, Boston; 'be Department of Molecular Biology, Massachusetts General Hospital and Department of Genetics, Harvard Medical School, Boston; ${ }^{\mathrm{c}}$ the Institute of Clinical Chemistry, Hannover Medical School; ${ }^{\mathrm{d}} \mathrm{Ge}-$ nentech, San Francisco; ${ }^{e}$ the Department of Medical Genetics, Hacettepe University Medical Faculty, Ankara; ${ }^{\mathrm{f}}$ Dr Sami Ulus Children's Health and Diseases Training and Research Center, Ankara; and ${ }^{g}$ Hacettepe University and Ihsan Doğramacı Children's Hospital, Ankara.

*These authors contributed equally to this work.

Supported by National Institutes of Health grants P01AI-076210 (to R.S.G.), AI-094017 (to R.S.G.), and T32 AI-007512-26 (to C.S.Y.); the Dubai-Harvard Foundation for Medical Research (to R.S.G.); the Perkins Fund (to R.S.G); a Jeffrey Modell Foundation Translational Research Program Grant Award (to J.C.); and the Hacettepe Scientific Research Projects Unit (BAP) Project 010-01-101-010 (to N.A.A., D.C.A., I.T., and O.S.).

Disclosure of potential conflict of interest: C. S. Yee has received a grant from the National Institutes of Health (NIH) and is employed by Boston Children's Hospital. W. Bainter is employed by Boston Children's Hospital. T. K. Ohsumi is employed by Seres Therapeutics, has patents through Massachusetts General Hospital and Seres Therapeutics, has received royalties from Massachusetts General Hospital, has stock options with Seres Therapeutics, and has received travel support from Google. N. Föger is employed by Hannover Medical School and Research Center Borstel and the Leibniz Center for Medicine and Biosciences and has received grants from DFG (German Research Foundation). A. C. Chan is employed by, has patents through, and has stock/stock options with Genentech. N. A. Akarsu, D. C. Ayvaz, I. Tezcan, and O. Sanal have received grants from Hacettepe Scientific Research Projects Unit (BAP; Project 010-01-101-010). R. S. Geha has received grants from the NIH, the DubaiHarvard Foundation for Medical Research, and the Perkins Fund and is employed by Boston Children's Hospital. J. Chou has received grants from the Jeffrey Modell Foundation Translational Research Program Grant Award and the National Institutes of Health and is employed by Boston Children's Hospital. The rest of the authors declare that they have no relevant conflicts of interest.

Received for publication February 5, 2015; revised July 26, 2015; accepted for publication August 4, 2015

Available online October 21, 2015

Corresponding author: Raif S. Geha, MD, Division of Immunology, Children's Hospital, Karp Building, 10th Floor, 1 Blackfan Circle, Boston, MA 02115. E-mail: Raif. Geha@childrens.harvard.edu.

(Q) The CrossMark symbol notifies online readers when updates have been made to the article such as errata or minor corrections

0091-6749/\$36.00

(C) 2015 American Academy of Allergy, Asthma \& Immunology

http://dx.doi.org/10.1016/j.jaci.2015.08.020
}

disseminated varicella, cutaneous warts, and $\mathrm{CD4}^{+}{ }^{+}$-cell lymphopenia.

Methods: We performed immunologic, genetic, and biochemical studies in the patients, family members, and healthy control subjects.

Results: Both patients had CD4 ${ }^{+}$T-cell lymphopenia and decreased lymphocyte proliferation to mitogens. IgG, IgM, IgA, and specific antibody responses were normal. Whole-genome sequencing identified a homozygous frameshift mutation in CORO1A disrupting the last $2 \mathrm{C}$-terminal domains by replacing 61 amino acids with a novel 91-amino-acid sequence. The CORO1A $^{\text {S401fs }}$ mutant was expressed in the patients' lymphocytes at a level comparable with that of wild-type CORO1A in normal lymphocytes but did not oligomerize and had impaired cytoskeletal association. CORO1A ${ }^{\text {S401fs }}$ was associated with increased filamentous actin accumulation in $\mathbf{T}$ cells, severely defective thymic output, and impaired T-cell survival but normal calcium flux and cytotoxicity, demonstrating the importance of CORO1A oligomerization and subcellular localization in T-cell homeostasis.

Conclusions: We describe a truncating mutation in CORO1A that permits protein expression and survival into young adulthood. Our studies demonstrate the importance of intact CORO1A C-terminal domains in thymic egress and T-cell survival, as well as in defense against viral pathogens. ( $\mathrm{J}$ Allergy Clin Immunol 2016;137:879-88.)

Key words: Coronin-1A, immunodeficiency, T-cell lymphopenia

Severe combined immunodeficiency (SCID) typically presents in infancy or early childhood with severe bacterial, viral, and/or fungal infections caused by mutations in genes important for T-cell and sometimes B-cell development. However, patients with hypomorphic mutations in genes classically associated with SCID can present with milder clinical presentations that include T-cell lymphopenia and adult-onset immunodeficiency. ${ }^{1-4}$ Coronin-1A (CORO1A) is an actin regulatory protein expressed primarily in hematopoietic cells and is critical for T-cell development and homeostasis. ${ }^{5-8}$ The first human mutation in the gene encoding CORO1A was identified in a patient with $\mathrm{T}^{-} \mathrm{B}^{+}$natural killer (NK) ${ }^{+}$SCID. ${ }^{9}$ As a rare cause of primary immunodeficiency described in only 4 kindreds thus far, all reported human mutations in $C O R O 1 A$ result in a complete lack of protein expression, resulting in $\mathrm{T}^{-} \mathrm{B}^{+} \mathrm{NK}^{+} \mathrm{SCID}$ or a 


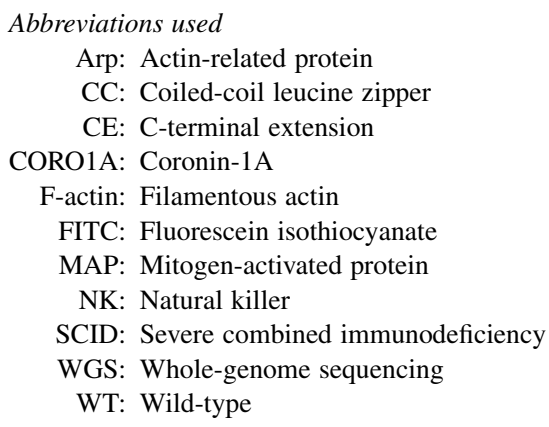

\section{Cell-culture and stimulation conditions}

PBMCs were separated by using Ficoll and then cultured in medium and stimulated with PHA (5 $\mu \mathrm{g} / \mathrm{mL}$; Sigma-Aldrich, St Louis, Mo) or anti-CD3 (5 $\mu \mathrm{g} / \mathrm{mL}$ OKT-3; eBioscience, San Diego, Calif) for 48 hours. EBV-transformed B cells were cultured from PBMCs by using standard techniques.

\section{Flow cytometry}

Standard flow cytometric methods were used for staining of cell-surface proteins. Anti-human mAbs to the following molecules with the appropriate isotype-matched controls were used for staining: CD3 (OKT-3), CD4 (RPA-T4), CD8 (HIT8a), CD19 (HIB19), CD56 (HCD56), CD16 (3G8), and Annexin V (BioLegend, San Diego, Calif). Data were collected with an LSRFortessa (BD Biosciences, San Jose, Calif) cell analyzer and analyzed with FlowJo software (Tree Star, Ashland, Ore).

\section{Calcium flux}

Calcium influx in PBMCs was measured by using flow cytometry with the Fluo-4 Direct Calcium Assay Kit in conjunction with $10 \mu \mathrm{g} / \mathrm{mL}$ Fura-Red (Life Technologies, Carlsbad, Calif), followed by staining with fluorescently labeled antibodies to CD4, CD8, or CD56. Immediately before measurement of calcium flux, cells were resuspended in Tyrode buffer solution containing $2 \mathrm{mmol} / \mathrm{L}$ calcium and analyzed on an LSRFortessa cell analyzer (BD Biosciences, San Jose, Calif). After 1 minute, either anti-CD $\varepsilon(10 \mu \mathrm{g} / \mathrm{mL})$ or anti-CD56 $(10 \mu \mathrm{g} / \mathrm{mL})$ was added to stimulate Tor NK cells, respectively. One minute later, $20 \mu \mathrm{g} / \mathrm{mL}$ goat anti-mouse secondary antibody was added to maximize cellular stimulation, and intracellular calcium levels were monitored for 300 seconds. The ratio of Fluo- 4 and Fura-Red emission was analyzed by using FlowJo software.

\section{Immunoblotting}

Lysates from EBV-transformed B cells were separated by means of SDS-PAGE, transferred to nitrocellulose membranes, and immunoblotted with a rabbit anti-CORO1A antibody specific for the N-terminus (SAB4200078, Sigma-Aldrich) or anti-glyceraldehyde-3-phosphate dehydrogenase (14C10; Cell Signaling, Danvers, Mass). Band intensities were quantified with ImageJ software (National Institutes of Health, Bethesda, Md).

\section{Transient transfections and coimmunoprecipitation}

The Myc- or FLAG-tagged wild-type (WT) human CORO1A constructs were developed by means of PCR amplification of human COROA1A cDNA (Open Biosystems, Pittsburgh, Pa) with standard cloning techniques. Myc- or FLAG-tagged mutant CORO1A expression constructs were generated from WT constructs by means of insertional mutagenesis with the QuikChange II system (Agilent, Santa Clara, Calif). FLAG-PYK2 was generated as previously described. ${ }^{18} 293 \mathrm{~T}$ cells were cotransfected with a specified combination of tagged CORO1A or PYK2 plasmids by using Transit-LT1 (Mirus Bio, Madison, Wis). After 48 hours, cells were lysed with $1 \%$ Triton-X100 buffer. Immunoprecipitation and immunoblotting were performed with an anti-FLAG (M2, Sigma-Aldrich) or anti-Myc (9E10, BioLegend) $\mathrm{mAb}$ and Protein G agarose (Calbiochem, Temecula, Calif).

\section{Lentiviral reconstitution of $\mathrm{T}$ cells from Coro1a $^{-1-}$ mice with WT or mutant Coro1a}

$\mathrm{T}$ cells were purified by means of negative selection from the spleens and lymph nodes of WT or Corola ${ }^{-1-}$ mice (Miltenyi Biotec, Auburn, Calif). Lentivirus was produced in $293 \mathrm{~T}$ cells after transfection with bicistronic pHAGE-zsGreen constructs (a kind gift from Richard Mulligan) containing either WT human CORO1A or mutant human CORO1A $\mathrm{A}^{\mathrm{p} . \mathrm{S} 401 \mathrm{fs}}$. Harvested

\section{cDNA sequencing}

mRNA from EBV-transformed B cells was sequenced with 3' RACE (Roche, Indianapolis, Ind), with nested sets of COROIA-specific and universal primers. 
A

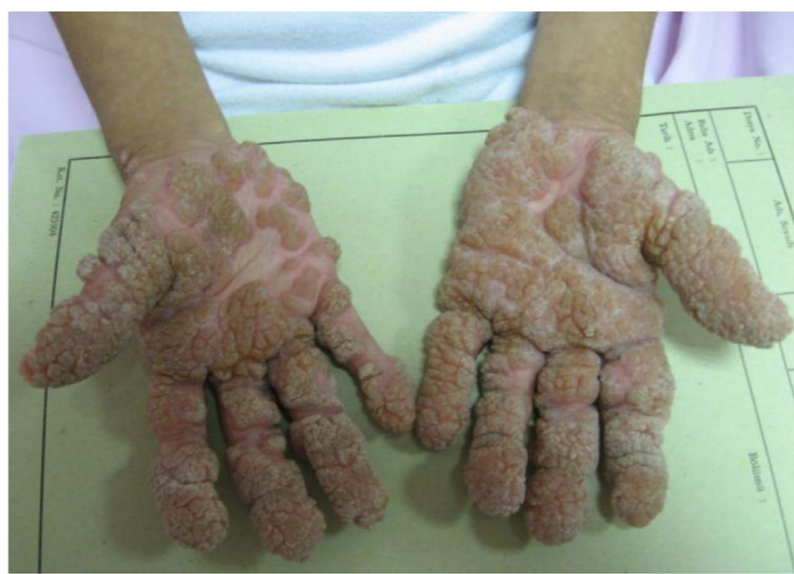

B

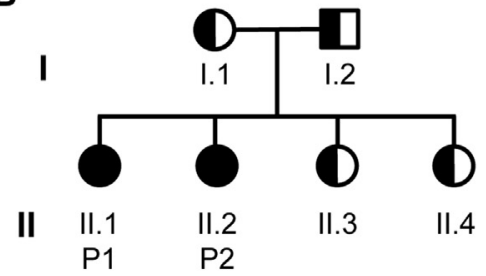

FIG 1. Cutaneous warts and family pedigree. A, Severe cutaneous warts in patient 1. B, Family pedigree. Solid symbols, Affected and homozygous for the p.S401fs mutant; half-solid symbols, carrier for the p.S401fs mutant.

lentiviral supernatants were filtered and concentrated by means of ultracentrifugation. Purified T cells were incubated with $3 \mu \mathrm{g} / \mathrm{mL}$ PHA and $8 \mu \mathrm{g} / \mathrm{mL}$ Polybrene (Sigma-Aldrich) and spin infected with viral supernatants for 1 hour at $700 \mathrm{~g}$. After a 12 -hour incubation, medium was replaced with complete RPMI containing IL-2 (100 IU/mL). Spin infection was repeated 8 hours later. Twelve hours after the second spin infection, cells were harvested, washed, and rested for 4 hours before staining for Annexin V and cell-surface markers.

\section{Subcellular fractionation of actin and CORO1A}

Subcellular fractionation was performed according to standard protocols. ${ }^{15}$ Briefly, $2 \times 10^{6}$ EBV-transformed B cells were washed 3 times in cold PBS. Isolation of the cytoskeleton-containing detergent-insoluble fraction was performed by carefully resuspending the harvested cell pellets in 10 volumes of ice-cold cytoskeletal isolation buffer (1\% Triton X-100 in $80 \mathrm{mmol} / \mathrm{L}$ piperazine- $\mathrm{N}, \mathrm{N}^{\prime}$-bis[2-ethanesulfonic acid], $\mathrm{pH} 6.8 ; 5 \mathrm{mmol} / \mathrm{L}$ ethyleneglycol-bis-[ $\beta$-aminoethylether]-N,N,N',N'-tetraacetic acid; and $1 \mathrm{~mol} / \mathrm{L} \mathrm{MgCl}_{2}$ ). After centrifugation at 3,000g and then at $100,000 \mathrm{~g}$, the soluble fraction was removed, and the Triton X-100-insoluble pellet was resuspended in an equal volume of loading buffer. Immunoblotting of cell lysates was performed with antibodies to CORO1A, actin, glyceraldehyde3 -phosphate dehydrogenase (14C10, Cell Signaling), and poly ADP ribose polymerase (PARP) (Santa Cruz Biotechnology, Santa Cruz, Calif).

\section{Cellular filamentous actin content}

Filamentous actin (F-actin) content was quantified by binding of fluorescein isothiocyanate (FITC)-labeled phalloidin (Cell Signaling). Briefly, $1 \times 10^{6}$ EBV-transformed B cells were permeabilized, incubated with FITC-labeled phalloidin on ice for 30 minutes, stained for cell-surface markers, and analyzed by using flow cytometry. The mean fluorescence intensity of FITC was measured in $\mathrm{CD} 4^{+}$cells.

\section{Cytotoxicity}

Cytotoxic cell killing of K562 target cells at 4 hours was measured by using a standard ${ }^{51} \mathrm{Cr}$ release assay. Degranulation of cytotoxic effectors was assessed by using a standard CD107a mobilization assay. Briefly, rested PBMCs were incubated for 4 hours with allophycocyanin-labeled anti-CD107a (BioLegend) and $5 \mu \mathrm{g} / \mathrm{mL}$ OKT or a 1:3 ratio of K562 cells in the presence of monensin, stained for cell-surface markers, and analyzed by means of flow cytometry. Unstimulated cells for each sample were used as controls.

\section{RESULTS \\ Clinical presentation and immunologic phenotyping}

Patient 1 and her younger female sibling, patient 2, were born to parents from the same village in Turkey. Before 2 years of age, patient 1 had extensive cutaneous warts and acute disseminated varicella virus infection with pneumonia and meningitis complicated by secondary encephalomalacia and seizures. She continues to have recurrent pulmonary infections, as well as chronic warts, particularly on her hands and feet (Fig 1, $A$ ), which only partially responded to cryotherapy, oral retinoids, and IFN- $\alpha$ injections. Her immunologic evaluation at 18 years of age was notable for $\mathrm{CD}^{+}$T-cell lymphopenia (299 cells/ $\mu \mathrm{L}$; normal, 700-2200 cells $/ \mu \mathrm{L})$, a decreased percentage of naive $\mathrm{CD}^{+}{ }^{+} \mathrm{CD} 45 \mathrm{RA}^{+} \mathrm{T}$ cells, and an increased percentage of memory $\mathrm{CD} 4{ }^{+} \mathrm{CD} 45 \mathrm{RA}^{-} \mathrm{T}$ cells but normal numbers of $\mathrm{CD}^{+} \mathrm{T}$ cells (541 cells/ $\mu \mathrm{L}$; normal, 490-1300 cells/ $\mu \mathrm{L})$, with a normal distribution of naive and memory $\mathrm{CD}^{+} \mathrm{T}$ cells (Table I). ${ }^{19-22}$ She had normal levels of $\operatorname{IgG}, \operatorname{IgA}$, and $\operatorname{IgM}$, with positive isohemagglutinin titers (anti-A, 1:64; anti-B, 1:32) and protective anti-herpes simplex virus IgG $(132 \mathrm{RU} / \mathrm{mL}$; protective, $>20 \mathrm{RU} / \mathrm{mL})$, anti-hepatitis A IgG (6.10 RU/mL; protective, $>1.2 \mathrm{RU} / \mathrm{mL}$ ), and anti-hepatitis B surface antibody (22.6 RU/ $\mathrm{mL}$; positive, $>10 \mathrm{RU} / \mathrm{mL})$. Subsequent $\mathrm{CD} 4^{+} \mathrm{T}$-cell counts ranged from 288 to 437 cells $/ \mu \mathrm{L}$ throughout childhood and early adulthood. Re-evaluation at 24 years of age was notable for borderline low normal numbers of $\mathrm{CD}^{+}{ }^{+} \mathrm{T}$ cells, increased $\mathrm{IgE}$ levels, and decreased lymphocyte proliferation to PHA, concanavalin A, and phorbol 12-myristate 13-acetate and ionomycin (Table I).

Patient 2 had chronic warts at 1.5 years of age. During childhood, she experienced 1 episode of bacterial pneumonia without further sinopulmonary infections. At 8 years of age, she also had disseminated varicella infection, which was successfully treated with intravenous acyclovir and intravenous immunoglobulin. Her immunologic evaluation at the time of infection was notable for $\mathrm{CD}^{+}{ }^{+}$T-cell lymphopenia (138 cells/ $\mu \mathrm{L}$; normal, 700-2200 cells $/ \mu \mathrm{L})$ and $\mathrm{CD}^{+}$lymphopenia $(184$ cells $/ \mu \mathrm{L}$; normal, 490-1300 cells/ $\mu \mathrm{L})$. She had a decreased percentage of naive $\mathrm{CD} 4^{+} \mathrm{T}$ cells with a concomitant increase in the percentage 
TABLE I. Immune profiles of the patients

\begin{tabular}{|c|c|c|}
\hline & Patient 1, 24 y & Patient 2, 14 y \\
\hline $\begin{array}{l}\text { Absolute lymphocyte count } \\
\quad(\text { cells } / \mu \mathrm{L})^{19}\end{array}$ & $1500(1200-5200)$ & $1800(1400-3300)$ \\
\hline \multicolumn{3}{|l|}{ Lymphocytes $(\text { cells } / \mu \mathrm{L})^{19}$} \\
\hline $\mathrm{CD}^{+}$ & $1140(536-1787)$ & $1116(1000-2200)$ \\
\hline $\mathrm{CD}^{+}{ }^{+} \mathrm{CD} 4^{+}$ & $375(309-1139)$ & $486(530-1300)$ \\
\hline $\mathrm{CD}^{+}{ }^{+} \mathrm{CD} 45 \mathrm{RA}^{+}(\%)$ & $12.2(50.1)^{*}$ & $8.5(50.1)$ \\
\hline $\mathrm{CD}^{+}{ }^{+} \mathrm{CD} 45 \mathrm{RA}^{-}(\%)$ & $87.8(49.9)$ & $91.5(49.9)$ \\
\hline $\mathrm{CD}^{+} \mathrm{CD}^{+}$ & $690(137-823)$ & $612(330-920)$ \\
\hline $\mathrm{CD}^{+} \mathrm{CD}^{2} 5 \mathrm{RA}^{+}(\%)$ & $32.3(45.5)^{*}$ & $43.2(45.5)$ \\
\hline $\mathrm{CD}^{+}{ }^{+} \mathrm{CD} 45 \mathrm{RA}^{-}(\%)$ & $67.7(54.6)$ & $56.7(54.6)$ \\
\hline $\mathrm{CD} 19^{+}$ & $165(72-460)$ & $324(110-570)$ \\
\hline $\mathrm{CD}_{16}{ }^{+} / \mathrm{CD} 6^{+}$ & $150(77-427)$ & $324(70-480)$ \\
\hline \multicolumn{3}{|l|}{ Immunoglobulins ${ }^{20}$} \\
\hline $\operatorname{IgG}(\mathrm{mg} / \mathrm{dL})$ & $701(608-1572)$ & $975(608-1572)$ \\
\hline $\operatorname{IgA}(\mathrm{mg} / \mathrm{dL})$ & $169(45-236)$ & $137(45-236)$ \\
\hline $\operatorname{IgM}(\mathrm{mg} / \mathrm{dL})$ & $175(52-242)$ & $81(52-242)$ \\
\hline $\operatorname{IgE}(\mathrm{IU} / \mathrm{mL})^{21,22}$ & $367(1.53-114)$ & $388(2.06-195.2)$ \\
\hline \multicolumn{3}{|c|}{ Lymphocyte proliferation $\left(\mathrm{cpm} \times 10^{3}\right)$} \\
\hline PHA & $16.2(52.6)$ & $28.1(52.6)$ \\
\hline Concanavalin A & $16.7(54.8)$ & $28.8(54.8)$ \\
\hline PMA/ionomycin & $45.9(80.4)$ & $24.5(80.4)$ \\
\hline Background & $2.8(5.2)$ & $1.5(5.2)$ \\
\hline
\end{tabular}

Values in parentheses represent the normal range for age. For lymphocyte proliferation studies, a healthy control subject was studied the same day as the patient. PMA, Phorbol 12-myristate 13-acetate.

*Normal value for percentages of naive and memory $\mathrm{T}$ cells were obtained by means of fluorescence-activated cell sorting analysis of a normal shipping control sample performed simultaneously with patient studies.

of memory $\mathrm{CD} 4^{+} \mathrm{T}$ cells but a normal distribution of naive and memory $\mathrm{CD}^{+} \mathrm{T}$ cells (Table I). After resolution of her infection, $\mathrm{CD}^{+}{ }^{+} \mathrm{T}$ cells ranged from 312 to 486 cells $/ \mu \mathrm{L}$ throughout childhood, and her $\mathrm{CD}^{+}$cell count normalized. She had normal levels of IgG, IgA, and IgM for her age, with positive isohemagglutinin titers (anti-A, 1:64; anti-B, 1:128). At 9 years of age, she had protective anti-herpes simplex virus IgG titers $(126 \mathrm{RU} / \mathrm{mL}$; protective, $>20 \mathrm{RU} / \mathrm{mL})$ and positive anti-hepatitis A IgG (5.1 $\mathrm{RU} / \mathrm{mL}$; protective, $>1.2 \mathrm{RU} / \mathrm{mL})$. Repeat immunologic evaluation at 14 years of age revealed increased IgE levels, as well as persistent $\mathrm{CD}^{+}{ }^{+}$lymphopenia with normal numbers of $\mathrm{CD}^{+}$cells and decreased proliferation to $\mathrm{T}$-cell mitogens (Table I).

\section{Identification of a homozygous frameshift mutation in CORO1A encoding a mutant form of CORO1A}

Microarray analysis of DNA from the 2 patients, their parents, and 1 healthy sibling (Fig 1, B, II.3) identified 2 regions of homozygosity shared exclusively by the 2 patients: chromosome 5 (GRCh37 position 2,615,632-4,725,405) and chromosome 16 (GRCh37 position 27,924,612-63,147,463). WGS of the 2 patients and their mother identified a total of 4 nonsynonymous variants in coding/splice sites that were within the $36-\mathrm{Mb}$ region of homozygosity on chromosome 16, homozygous in both patients, heterozygous in their mother, and absent from the dbSNP and 1000 Genome databases (see Table E1 in this article's Online Repository at www.jacionline.org). No variants were identified in the much smaller, approximately $2-\mathrm{Mb}$ region of homozygosity on chromosome 5. A single nucleotide insertion in CORO1A (1191_1192insC) was the most likely causative candidate mutation because of the critical role of CORO1A in maintaining T-cell homeostasis. Sanger sequencing of genomic DNA confirmed that the mutation was present in the homozygous state in both patients and heterozygous in both parents (Fig 2, A) and the 2 unaffected siblings (data not shown).

The mutation is predicted to create a frameshift after amino acid 400 (p.Ser401fs), resulting in substitution of the $61 \mathrm{C}$-terminal amino acids that encode part of the $\mathrm{CE}$ and the entire CC domain, with a novel 91-amino-acid sequence that extends 30 residues beyond the stop codon in the normal transcript (Fig 2, B). This was confirmed by means of $3^{\prime}$ RACE sequencing of mRNA from EBV-transformed $\mathrm{B}$ cells derived from patient 1 and a healthy control subject (data not shown). Immunoblot analysis of the patients' EBV-transformed B-cell lysates revealed expression of a mutant CORO1A protein with a molecular weight higher than that of the WT protein (Fig 2, $C$ ). The patients' mother, who is heterozygous for the mutation, expresses both WT and mutant CORO1A protein (Fig 2, C). Furthermore, CORO1A $\mathrm{A}^{\mathrm{S} 401 \mathrm{fs}}$ is expressed in the patients' EBV-transformed B cells at a level comparable with that of WT CORO1A in normal EBV-transformed B cells (Fig 2, D).

\section{The CORO1A mutation disrupts protein oligomerization}

The C-terminal CC domain (amino acids 429-461) of CORO1A is required for its oligomerization and cytoskeletal association. ${ }^{14,23}$ We examined whether the patients' mutant CORO1A protein, which lacks the entire CC domain, oligomerizes. The association of Myc-tagged and FLAG-tagged WT and mutant CORO1A in transiently transfected HEK293T cells was assessed by means of coimmunoprecipitation. As expected, FLAG-tagged WT CORO1A coimmunoprecipitated with Myc-tagged WT CORO1A (Fig 3, A, lane 1). In contrast, FLAG-tagged mutant CORO1A did not coimmunoprecipitate with Myc-tagged mutant CORO1A (Fig 3, A, lane 2) or Myc-tagged WT CORO1A (Fig 3, A, lane 3). FLAG-tagged PYK2, which was used as a negative control, did not coimmunoprecipitate with WT CORO1A (Fig 3, A, lane 4). These data indicate that oligomerization is abolished in the CORO1A ${ }^{\mathrm{S} 401 \mathrm{fs}}$ mutant. Because the mutant does not associate with the WT protein, it would not be expected to exert a dominant negative effect. This is consistent with the absence of clinical disease in the patients' parents and siblings, who are heterozygous for the mutation.

\section{Abnormal subcellular distribution of the CORO1A mutant protein and increased F-actin levels in the patients' $T$ cells}

CORO1A associates with the actin cytoskeleton, binds to F-actin, and localizes at sites of actin assembly. ${ }^{13,24,25}$ Overexpression studies in HEK293T cells have shown that the association of CORO1A with the cytoskeleton requires the $\mathrm{CE}$ domain (amino acids 352-429). ${ }^{14}$ We compared the subcellular distribution of the CORO1A ${ }^{\mathrm{S} 401 \mathrm{fs}}$ mutant, which lacks the C-terminal half of the CE domain (amino acids 401-429) and the entire CC domain with that of WT CORO1A by using high-speed centrifugation to fractionate the soluble cytosolic proteins from the insoluble cytoskeletal components in EBV-transformed B cells from the patients and control subjects. 
A

\section{Normal Control}

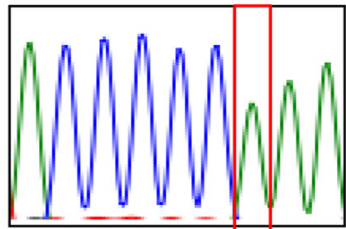

WT A C C C C CAA A

WT A C C C C CAA A

Patient 1

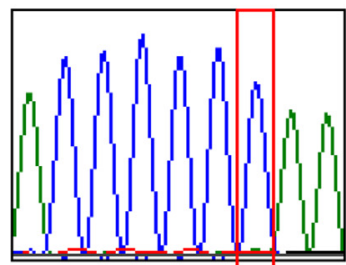

Mut $A C C C C C D A A$

Mut $A C C C C C C A A$
Mother

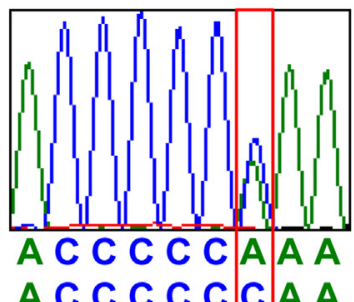

Mut $A C C C C C C A A$

Patient 2

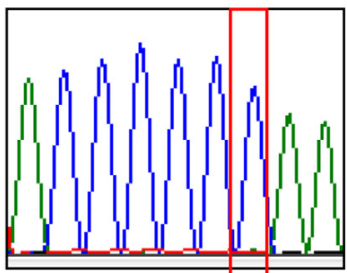

Mut ACC C C CA A

Mut $A C C C C C D A A$

B

WT

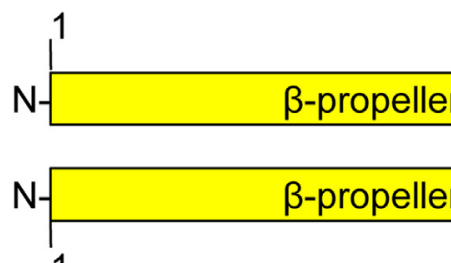

1

352

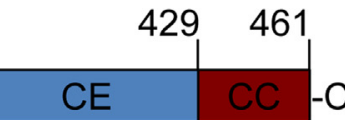

Mut

C
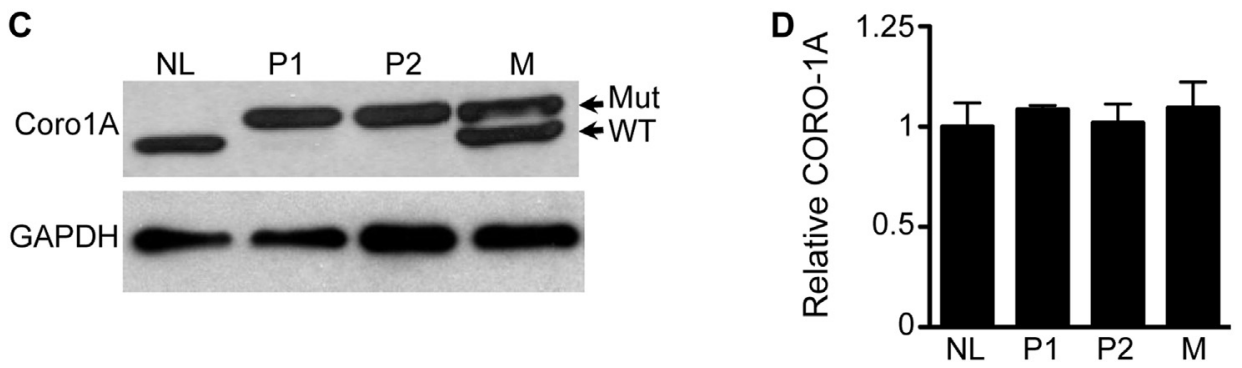

FIG 2. Sanger sequencing of the CORO1A mutation and analysis of the CORO1A $\mathrm{A}^{\mathrm{p} . \mathrm{S} 401 \mathrm{fs}}$ mutant. A, Sanger sequencing demonstrating the CORO1A mutation (1191_1192insC) in the homozygous state in the patients and in the heterozygous state in their mother. Sequencing of a control subject is included. B, Schematic of WT and mutant (Mut) CORO1A. The CORO1A ${ }^{\mathrm{S} 401 \mathrm{fs}}$ has the last $\mathrm{C}$-terminal 61 amino acids replaced by a novel 91-amino-acid sequence. C, Immunoblot analysis of CORO1A in lysates of EBV-transformed B cells from a control subject $(N L)$, patients 1 and 2 ( $P 1$ and $P 2)$, and the patient's mother $(M)$. The mutant CORO1$A^{\text {S401fs }}$ (Mut) migrates at a higher molecular weight. GAPDH, Glyceraldehyde-3-phosphate dehydrogenase. D, Quantitative analysis of protein expression. The CORO1A/GAPDH ratio from the patients' cells was normalized to that of a control subject to calculate relative CORO1A expression. Columns and bars represent means and SEs and are representative of 3 experiments.

WT CORO1A distributed nearly equally between the cytosolic and cytoskeletal fractions of control EBV-transformed B cells (Fig 3, B). In contrast, the CORO1A ${ }^{\mathrm{S} 401 \mathrm{fs}}$ mutant localized predominantly to the cytosolic fraction in EBV-transformed B cells from patient 1 (Fig 3, B). Quantitative analysis of results from 2 experiments demonstrated that a significantly higher fraction of mutant CORO1A (85.0\%) was cytosolic in the patients' cells compared with the fraction of cytosolic WT CORO1A (49.3\%) in control cells (Fig 3,C). These data demonstrate a disrupted association of the CORO1A $\mathrm{A}^{\mathrm{S} 401 \mathrm{fs}}$ mutant with the cytoskeleton in the patients' cells.

In addition to its role in oligomerization, the $\mathrm{CC}$ domain is necessary for the inhibitory role of CORO1A on actin-related protein (Arp) 2/3-dependent F-actin branching and accumulation. ${ }^{5,25,26}$ Resting T cells from Corola ${ }^{-1-}$ mice have increased cellular F-actin content, which is consistent with the absence of CORO1A-mediated inhibition of F-actin accumulation. ${ }^{5,9}$ Because CORO1 $\mathrm{A}^{\text {Ser401fs }}$ lacks the CC domain, 
A WT-CoR01A-Myc WT-CORO1A-FLAG

Mut-CORO1A-Myc

Mut-CORO1A-FLAG

PYK2-FLAG
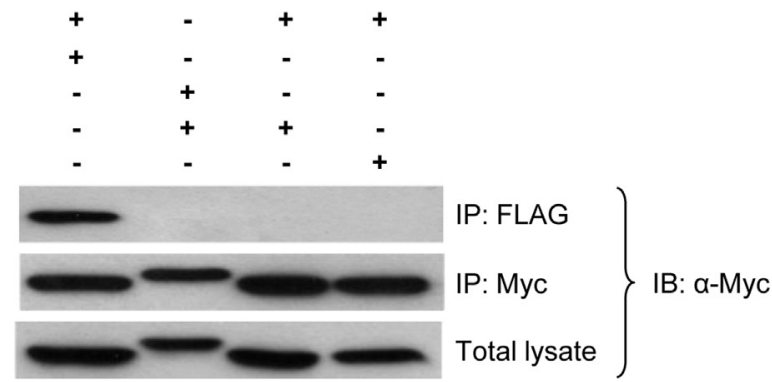

B

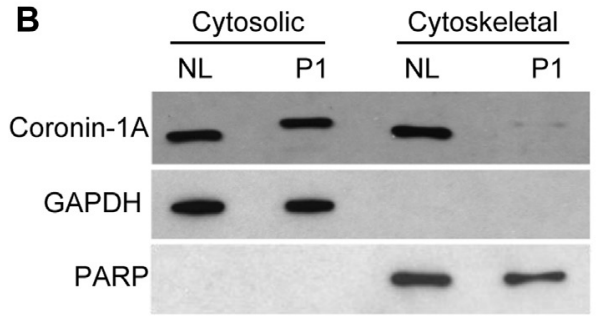

D

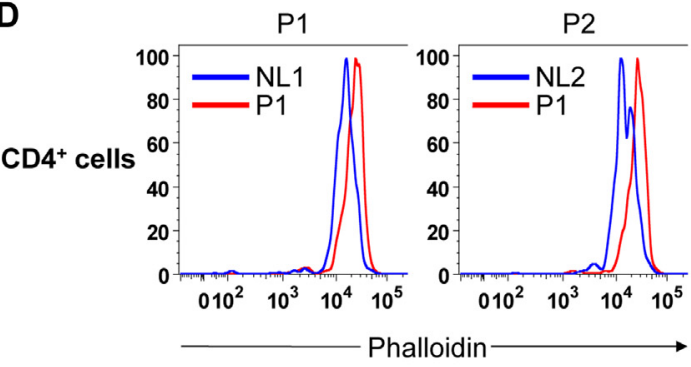

P1

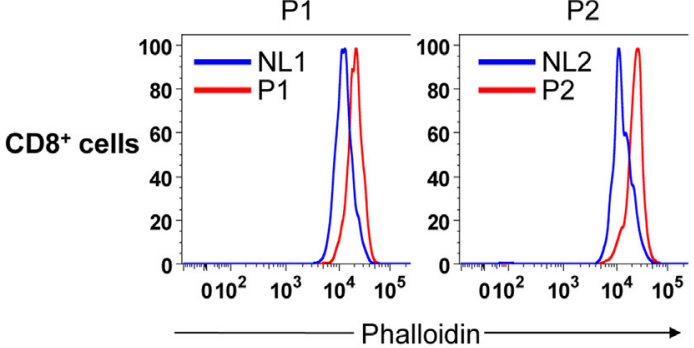

C
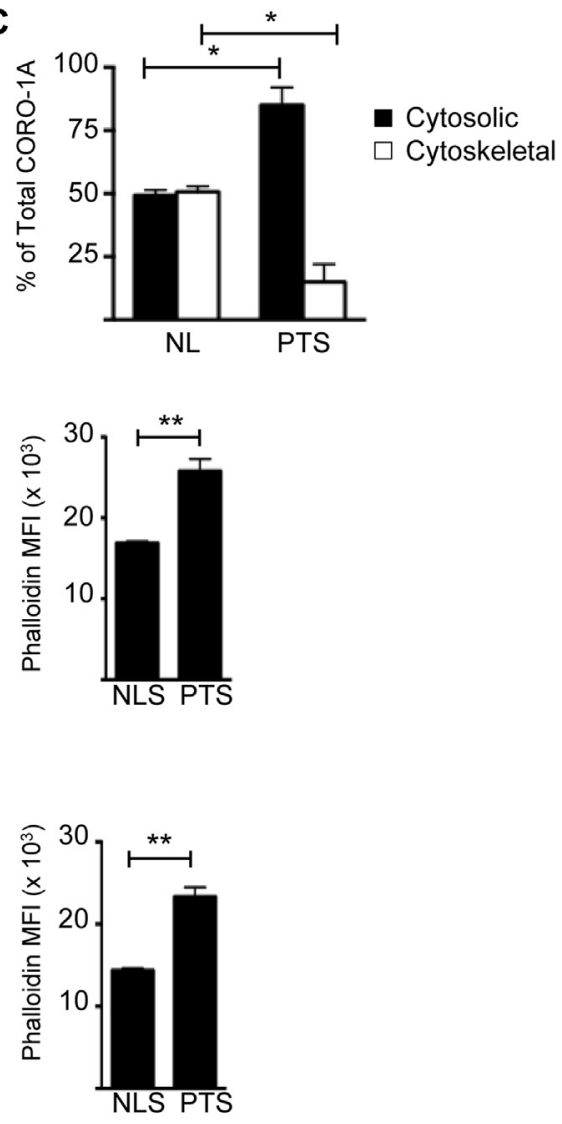

FIG 3. Oligomerization and cytoskeletal distribution of the CORO1A $\mathrm{S}^{\mathrm{S} 401 \mathrm{fs}}$ mutant. A, Coimmunoprecipitation of WT and mutant (Mut) CORO1A in lysates from HEK293T cells cotransfected with combinations of Myc- and FLAG-tagged WT and Mut-CORO1A and FLAG-tagged PYK2 as a negative control. Myc- and FLAG immunoprecipitates (IP) and total cell lysates were immunoblotted with anti-Myc antibody. B, Immunoblot analysis of CORO1A in cytosolic and cytoskeletal fractions from EBV-B cells of a healthy control subjects $(N L)$ or patient (P1). Glyceraldehyde-3-phosphate dehydrogenase (GAPDH) and PARP were immunoblotted as markers for cytosolic and cytoskeleton-associated proteins, respectively. C, Quantification of CORO1A distribution in the cytosolic and cytoskeletal fractions. Columns and bars represent means and SEs of 2 independent experiments. ${ }^{*} P<.05$. D, Assessment of F-actin content in CD4 ${ }^{+}$and CD8 ${ }^{+} \mathrm{T}_{\text {cells }}$ of patients ( $P 1$ and $P 2)$ and control subjects ( $N L 1$ and $N L 2)$. Left, Representative flow cytometric analysis of phalloidin staining. Right, Quantification of F-actin content. Columns and bars represent means and SEs in 2 patients and 2 control subjects. ${ }^{*} P<.01$. 
A

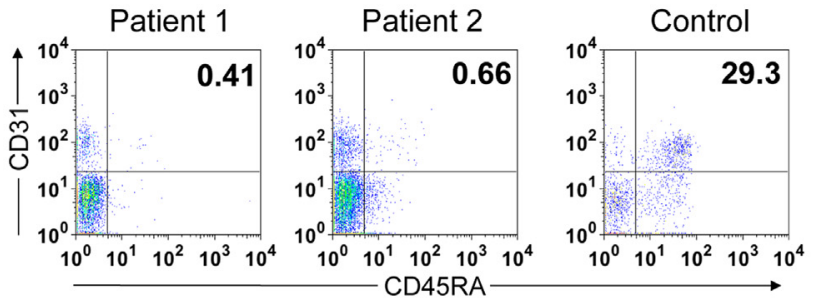

B

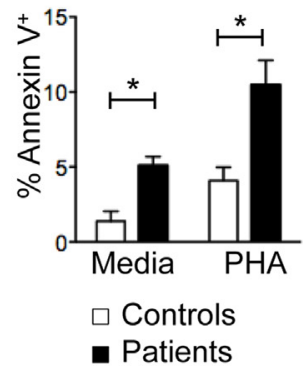

C
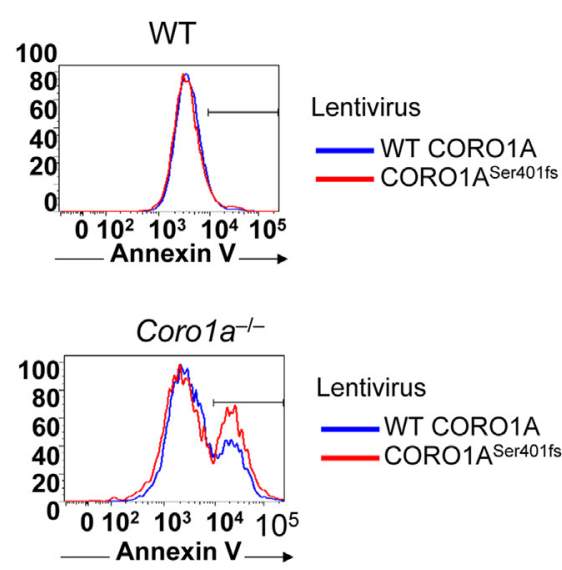

E

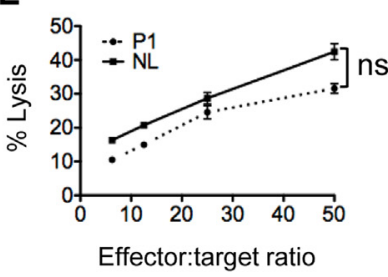

Lentivirus

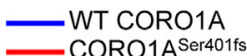

D
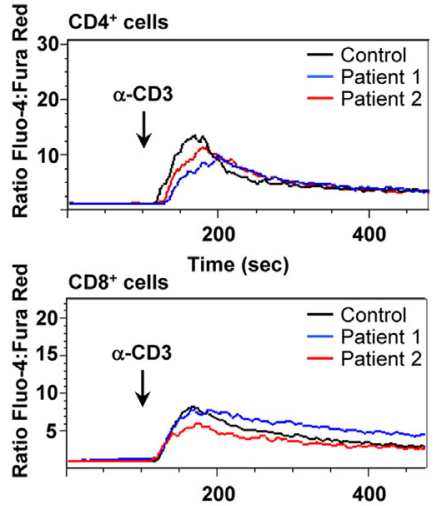

¿ $\mathrm{CD}^{+} 6^{+}$cells Time $(\mathrm{sec})$

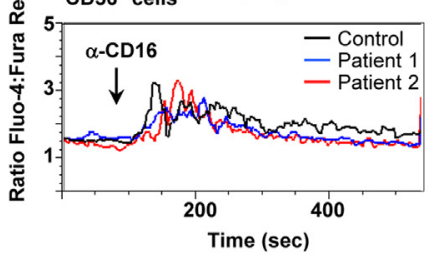

$\mathbf{F}$

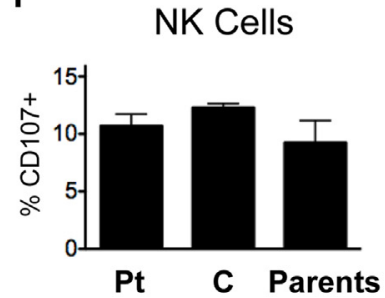

G

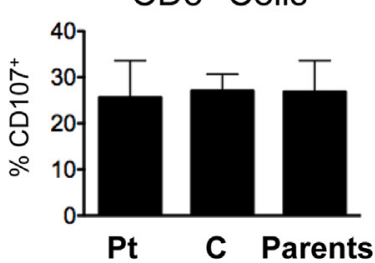

FIG 4. CORO1A $\mathrm{A}^{\mathrm{S} 401 \mathrm{fs}}$ results in decreased thymic output and increased peripheral T-cell apoptosis but does not affect calcium flux or cytotoxicity in vitro. A, Flow cytometric analysis of $\mathrm{CD} 4^{+} \mathrm{CD} 31^{+} \mathrm{CD} 45 \mathrm{RA} \mathrm{A}^{+}$recent thymic emigrants in the patients and a control subject. Cells were gated on $\mathrm{CD}^{+}{ }^{+} \mathrm{T}$ cells. B, Cell-surface Annexin $\mathrm{V}^{+}$in $\mathrm{CD}^{+} \mathrm{T}$ cells in patients (solid bars) or control subjects (open bars) cultured with medium or PHA for 48 hours, as assessed by using flow cytometry. Results represent means and SEs of the percentage of Annexin $\mathrm{V}^{+}$cells in 2 patients and 5 healthy control subjects. C, Flow cytometry of Annexin $\mathrm{V}^{+}$binding to $\mathrm{CD}^{+}$WT T cells versus Coro1 $\mathrm{a}^{-1-}$ T cells transduced with a lentivirus vector encoding for WT CORO1A or $\mathrm{CORO}^{\mathrm{S}} \mathrm{S}^{\mathrm{T} 1 \mathrm{fs}}$ and $\mathrm{ZsGreen}$ fluorescent protein. Cells are gated on $\mathrm{CD} 4^{+} \mathrm{ZsGreen}^{+}$cells. Data are representative of 4 mice for each genotype done in 2 different experiments. D, Calcium flux in $\mathrm{CD}^{+}{ }^{+}$(top panel) and $\mathrm{CD}^{+}$(middle panel) cells stimulated with anti-CD3 from patients. Lower panel, NK cell calcium flux after anti-CD56 stimulation. Patient 1, Blue; patient 2, red; healthy control subject, black. E, Cytotoxic cell killing of $\mathrm{K} 562$ target cells by PBMCs in the ${ }^{51} \mathrm{Cr}$ release assay. The means and SEs of 4 replicates are shown. $n s$, Not significant. F, CD107a expression on $\mathrm{CD}^{-} \mathrm{CD}^{-} 6^{+} \mathrm{NK}$ cells after stimulation with $\mathrm{K} 562$ target cells. G, CD107a expression on $\mathrm{CD}^{+}{ }^{+} \mathrm{CD}^{+}$cells after anti-CD3 stimulation. For Fig $4, E$ and $F$, percentages of stimulated CD107a ${ }^{\text {high }}$ cells are shown. Graphs show means and SEs for 2 independent experiments.

we determined the effect of CORO1A $\mathrm{A}^{\text {Ser401fs }}$ on F-actin content by examining the binding of FITC-labeled phalloidin to F-actin in permeabilized $\mathrm{CD}^{+} \mathrm{T}$ cells from the patients and control subjects (Fig 3, D, left panels). The F-actin content of the patients' $\mathrm{CD} 4^{+}$and $\mathrm{CD} 8^{+} \mathrm{T}$ cells was significantly higher than that of control T cells (Fig 3, D, right panel), indicating the importance of an intact $\mathrm{CE}$ and $\mathrm{CC}$ domains in regulating T-cell actin dynamics.

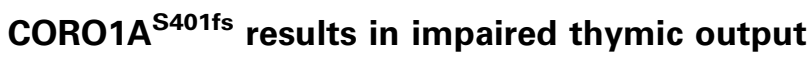
and peripheral T-cell survival but normal signaling and degranulation of $T$ and NK cells

Complete absence of CORO1A has been associated with defective T-cell egress and survival. ${ }^{5,9}$ Quantification of $\mathrm{CD} 4{ }^{+} \mathrm{CD} 31^{+} \mathrm{CD} 45 \mathrm{RA}^{+}$recent thymic emigrants in both patients demonstrated that CORO1A $\mathrm{A}^{\text {Ser401fs }}$ severely impairs thymic 
output (Fig 4, A). Furthermore, resting and PHA-stimulated $\mathrm{CD}^{+} \mathrm{T}$ cells in both siblings had increased Annexin $\mathrm{V}$ staining compared with control cells, indicating that the patients' CD4 ${ }^{+}$ lymphopenia stemmed from defective T-cell survival, as well as decreased thymic output. The patients had normal upregulation of the activation markers CD25 and CD69 and IL-2 secretion after 2 days of either PHA or anti-CD3 stimulation (see Fig E1 in this article's Online Repository at www.jacionline.org). Annexin $\mathrm{V}^{+}$ staining was not increased in the patients' B or NK cells (data not shown). Furthermore, we reconstituted $\mathrm{T}$ cells from Corola $a^{-/-}$ mice with either WT CORO1A or CORO1A ${ }^{\text {Ser401fs }}$ through lentiviral transduction. WT $\mathrm{T}$ cells transduced with lentivirus encoding CORO1A ${ }^{\text {Ser401fs }}$ did not have increased Annexin $\mathrm{V}^{+}$ staining compared with those transduced with WT CORO1A (Fig 4, C, upper panel), indicating that CORO1A $\mathrm{A}^{\text {Ser401fs }}$ does not have a dominant negative effect on T-cell survival. In contrast, lentiviral transduction with WT CORO1A, but not the CORO1A ${ }^{\text {Ser401fs }}$ mutant, reduced apoptosis in Corola ${ }^{-/-}$ $\mathrm{T}$ cells, demonstrating the detrimental effect of CORO1A ${ }^{\mathrm{S} 401 \mathrm{fs}}$ on T-cell survival (Fig 4, C, lower panel).

The recurrent infections associated with complete CORO1A deficiency have been attributed to T-cell lymphopenia, as well as to impaired T-cell and NK cell activation, leading to defective cytotoxicity. ${ }^{8,13}$ In contrast to previously published studies of Corola ${ }^{-1-}$ mice, ${ }^{7,8}$ patients with the CORO1A $\mathrm{Aer}^{\text {Solfs }}$ mutant had very modest to no decrease in calcium flux in $\mathrm{T}$ cells stimulated with anti-CD3 mAb and in NK cells stimulated with anti-CD56 mAb (Fig 4, D). PBMCs from both patients demonstrated normal cytotoxic cell killing of K562 target cells at 4 hours, as measured by using a standard ${ }^{51} \mathrm{Cr}$ release assay (Fig 4, E). NK cells from both patients had normal upregulation of CD107a surface expression in response to incubation with K562 target cells consistent with normal degranulation (Fig 4, $F$ ). In addition, $\mathrm{CD}^{+} \mathrm{T}$ cells from both patients had normal upregulation of $\mathrm{CD} 107 \mathrm{a}$ surface expression in response to anti-CD3 stimulation (Fig 4, $G$ ). Therefore although the $\mathrm{CC}$ and $\mathrm{CE}$ domains are critical for the role of CORO1A in actin dynamics, T-cell egress, and survival, these domains are dispensable for calcium flux and cytotoxicity.

\section{DISCUSSION}

We report a truncating mutation in COROIA as a cause of $\mathrm{CD}^{+}$lymphopenia in 2 young adults with recurrent viral infections. CORO1A deficiency has been associated with SCID and, more recently, a combined immunodeficiency presenting in childhood with recurrent viral infections and susceptibility to lymphoproliferative disorders. ${ }^{9-13}$ Unlike previously published patients, who all demonstrated complete CORO1A deficiency, ${ }^{9-13}$ the patients in this report have a novel CORO1A mutation that permits expression of a mutant CORO1A lacking intact CE and CC domains. Overexpression studies in HEK293T cells have identified the role of the $\mathrm{CE}$ and $\mathrm{CC}$ domains in CORO1A oligomerization and its subcellular distribution. ${ }^{14}$ Our report builds on these in vitro data by demonstrating the importance of these domains for T-cell survival in vivo and host defense against viruses but not for calcium flux or $\mathrm{CD}^{+}$or NK cell cytotoxicity. Importantly, the patients in this report continue to survive into young adulthood without an SCID phenotype or lymphoproliferative disease, thus expanding the phenotype associated with COROIA mutations.
CORO1A regulates actin dynamics by binding to F-actin, which accumulates at the leading edge of migrating $\mathrm{T}$ cells, the immune synapse of NK cells, and the phagocytic vesicles of neutrophils and macrophages. ${ }^{9,13,23,27,28}$ The CC domain of CORO1A negatively regulates F-actin assembly by binding to and inhibiting the Arp2/3 complex, which is important for the growth of actin filaments. ${ }^{29,30}$ We demonstrate that CORO1$\mathrm{A}^{\text {S401fs }}$, which lacks an intact $\mathrm{CC}$ domain, leads to higher F-actin content in the patients' $T$ cells. Additionally, the CORO1A ${ }^{\text {S401fs }}$ mutant distributes predominantly to the cytosolic fraction in contrast to the even distribution of WT CORO1A between the cytosolic and cytoskeletal fractions in control cells. This is in agreement with in vitro studies demonstrating that deletion of key residues in the $\mathrm{CE}$ domain redistribute CORO1A to the cytosolic compartment. ${ }^{14}$ Sequestration of CORO1A ${ }^{\text {S401fs }}$ in the cytosolic compartment impairs its ability to bind F-actin and thus might prevent the mutant from enhancing cofilin-mediated F-actin disassembly. This might contribute further to the defective actin dynamics and abnormal accumulation of F-actin in the patients' T cells.

Both patients had CD ${ }^{+}$T-cell lymphopenia with profoundly decreased recent thymic emigrants and increased $\mathrm{CD} 4^{+}$T-cell apoptosis, demonstrating defects in impaired thymic output and T-cell survival that have also been observed in Corola ${ }^{-1-}$ mice. ${ }^{5}$ CORO1A deficiency leads to increased T-cell apoptosis beginning at the single positive thymocyte stage and is associated with cleavage of caspase 3 and 9, increased release of cytoplasmic cytochrome c, and decreased mitochondrial membrane potential. ${ }^{5,8,9}$ Impaired T-cell survival in Corola $a^{-/-}$mice has been attributed to defective calcium flux after anti-CD3 stimulation. ${ }^{7,9}$ However, calcium flux in our patients' $\mathrm{CD} 4^{+}$ and $\mathrm{CD}^{+} \mathrm{T}$ cells after anti-CD3 stimulation was minimally decreased, indicating that calcium flux is not the sole mechanism through which CORO1A regulates T-cell survival. Accumulation of F-actin has been proposed as an alternative mechanism underlying the enhanced apoptosis seen in Corola $a^{-1-} \mathrm{T}$ cells, which was partially reversed by actin-depolarizing agents. ${ }^{5}$ Similarly, activating mutations in Wiskott-Aldrich protein associated with $\mathrm{X}$-linked neutropenia perturb the regulation of actin assembly by the Arp $2 / 3$ complex, leading to enhanced actin polymerization, increased basal F-actin content, and increased apoptosis. $^{31}$ In our patients we propose that the failure of $\mathrm{CORO}^{\mathrm{S}} \mathrm{S}^{\mathrm{folfs}}$ to oligomerize and associate with the cytoskeleton leads to abnormal accumulation of F-actin and impaired T-cell survival.

Both patients demonstrated increased susceptibility to varicella virus and chronic warts, which are typically caused by human papilloma virus. Severe varicella virus infection, as well as EBV-associated lymphoproliferative disease, has been reported in patients with CORO1A deficiency. ${ }^{9,11,13}$ Additionally, Corol $a^{-1-}$ mice are particularly vulnerable to vesicular stomatitis virus because of impaired $\mathrm{CD}^{+}{ }^{+}$T-cell function. ${ }^{32}$ Our short-term killing assays, which place $\mathrm{T}$ and $\mathrm{NK}$ cells in direct contact with target cells, did not reveal defects in cytotoxicity. In patients with dedicator of cytokinesis 8 deficiency, another primary immunodeficiency characterized by recurrent viral infections, abnormalities in actin dynamics lead to increased cell death during lymphocyte migration through tissues, resulting in increased susceptibility to viral infections of the skin. ${ }^{33}$ Similarly, patients with dedicator of cytokinesis 2 deficiency have both an increased susceptibility to invasive viral infections because of 
defective actin polymerization and T- and B-cell chemotaxis. ${ }^{34}$ Therefore in vitro cytotoxicity assays might not reflect the full effect of CORO1A ${ }^{\text {S401fs }}$ on host defense against viral pathogens in vivo, which requires the migration of $\mathrm{T}$ and $\mathrm{NK}$ cells to the site of infections.

Unlike previously described patients with CORO1A mutations who died at a young age or required hematopoietic stem cell transplantation, $9,10,12$ our patients continue to survive into young adulthood and have not had sufficient recurrent infections to warrant hematopoietic stem cell transplantation as curative therapy. The CORO1A ${ }^{\mathrm{S} 401 \mathrm{fs}}$ in our patients is a truncated mutant with a preserved $\beta$-propeller domain, which comprises approximately $76 \%$ of the normal protein ${ }^{14}$ and part of the CE domain. Previously published in vitro studies of a CORO1A truncation mutant that retains the $\beta$-propeller domain but lacks the $\mathrm{CC}$ and $\mathrm{CE}$ domains revealed preserved CORO1A binding to the plasma membrane, demonstrating the role of the $\beta$-propeller domain in association of CORO1A with the cell membrane. CORO1A deficiency results in severely impaired T-cell calcium flux and defective NK cell cytotoxicity. 8,13 Notably, our patients had intact T-cell and NK cell calcium flux, NK cell cytotoxicity, and $\mathrm{NK}$ and $\mathrm{CD}^{+}$cell degranulation, demonstrating that the $\beta$-propeller domain, rather than the $\mathrm{CC}$ or CE domains, is important for calcium flux and cytotoxicity, and these functions can occur in the absence of CORO1A oligomerization. Furthermore, the impaired calcium flux previously seen in CORO1A-deficient $\mathrm{T}$ cells has been associated with defective activation of the mitogen-activated protein (MAP) kinases. ${ }^{7,12}$ In contrast, our patients had normal IL-2 production after anti-CD3 and PHA stimulation, demonstrating intact MAP kinase signaling downstream of T-cell receptor activation because IL-2 secretion depends on MAP kinase signaling. ${ }^{35}$ Collectively, these findings indicate that the $\mathrm{CORO} 1 \mathrm{~A}^{\mathrm{S} 401 \mathrm{fs}}$ mutant retains partial activity, which, in addition to genetic background differences, environmental exposures, and epigenetic factors, might explain the milder clinical phenotype of our patients.

We report 2 adults with a frameshift mutation in the $\mathrm{C}$-terminal domain of CORO1A, leading to defective protein oligomerization, abnormal subcellular localization, and F-actin accumulation. Our data provide in vivo evidence of the link between CORO1A oligomerization, its regulation of actin dynamics, and T-cell survival. Furthermore, the clinical presentation of these patients broadens the phenotype of human disease associated with mutations in $C O R O 1 A$, underscoring the importance of considering it a genetic diagnosis in patients with $\mathrm{CD} 4^{+} \mathrm{T}$-cell lymphopenia and susceptibility to viral infections.

We thank the patients and their families for providing samples and Baran Erman and Fatima Aers Kaya for performing the recent thymic emigrant studies.

Clinical implications: The C-terminal domains of CORO1A are essential for thymic output and T-cell survival. CORO1A mutations should be considered in patients with T-cell lymphopenia and chronic viral infections.

\section{REFERENCES}

1. Abraham RS, Recher M, Giliani S, Walter JE, Lee YN, Frugoni F, et al. Adult-onset manifestation of idiopathic T-cell lymphopenia due to a heterozygous RAG1 mutation. J Allergy Clin Immunol 2013;131:1421-3.
2. Kuijpers TW, Ijspeert H, van Leeuwen EM, Jansen MH, Hazenberg MD Weijer $\mathrm{KC}$, et al. Idiopathic $\mathrm{CD} 4+\mathrm{T}$ lymphopenia without autoimmunity or granulomatous disease in the slipstream of RAG mutations. Blood 2011; 117:5892-6.

3. Shovlin CL, Simmonds HA, Fairbanks LD, Deacock SJ, Hughes JM, Lechler RI, et al. Adult onset immunodeficiency caused by inherited adenosine deaminase deficiency. J Immunol 1994;153:2331-9.

4. Ban SA, Salzer E, Eibl MM, Linder A, Geier CB, Santos-Valente E, et al Combined immunodeficiency evolving into predominant CD4+ lymphopenia caused by somatic chimerism in JAK3. J Clin Immunol 2014;34:941-53.

5. Foger N, Rangell L, Danilenko DM, Chan AC. Requirement for coronin 1 in T lymphocyte trafficking and cellular homeostasis. Science 2006;313:839-42.

6. Jayachandran R, Sundaramurthy V, Combaluzier B, Mueller P, Korf H, Huygen K, et al. Survival of mycobacteria in macrophages is mediated by coronin 1-dependent activation of calcineurin. Cell 2007;130:37-50.

7. Mueller P, Massner J, Jayachandran R, Combaluzier B, Albrecht I, Gatfield J, et al. Regulation of $\mathrm{T}$ cell survival through coronin-1-mediated generation of inositol-1,4,5-trisphosphate and calcium mobilization after $\mathrm{T}$ cell receptor triggering. Nat Immunol 2008;9:424-31.

8. Mugnier B, Nal B, Verthuy C, Boyer C, Lam D, Chasson L, et al. Coronin-1A links cytoskeleton dynamics to TCR alpha beta-induced cell signaling. PLoS One 2008;3: e3467.

9. Shiow LR, Roadcap DW, Paris K, Watson SR, Grigorova IL, Lebet T, et al The actin regulator coronin $1 \mathrm{~A}$ is mutant in a thymic egress-deficient mouse strain and in a patient with severe combined immunodeficiency. Nat Immunol 2008;9: 1307-15.

10. Shiow LR, Paris K, Akana MC, Cyster JG, Sorensen RU, Puck JM. Severe combined immunodeficiency (SCID) and attention deficit hyperactivity disorder (ADHD) associated with a Coronin-1A mutation and a chromosome 16p11.2 deletion. Clin Immunol 2009:131:24-30.

11. Stray-Pedersen A, Jouanguy E, Crequer A, Bertuch AA, Brown BS, Jhangiani SN, et al. Compound heterozygous CORO1A mutations in siblings with a mucocutaneous-immunodeficiency syndrome of epidermodysplasia verruciformisHPV, molluscum contagiosum and granulomatous tuberculoid leprosy. J Clin Immunol 2014;34:871-90.

12. Moshous D, Martin E, Carpentier W, Lim A, Callebaut I, Canioni D, et al Whole-exome sequencing identifies Coronin-1A deficiency in 3 siblings with immunodeficiency and EBV-associated B-cell lymphoproliferation. J Allergy Clin Immunol 2013;131:1594-603.

13. Mace EM, Orange JS. Lytic immune synapse function requires filamentous actin deconstruction by Coronin 1A. Proc Natl Acad Sci U S A 2014;111: 6708-13.

14. Gatfield J, Albrecht I, Zanolari B, Steinmetz MO, Pieters J. Association of the leukocyte plasma membrane with the actin cytoskeleton through coiled coil-mediated trimeric coronin 1 molecules. Mol Biol Cell 2005;16: 2786-98.

15. Carnevali P, Baccash J, Halpern AL, Nazarenko I, Nilsen GB, Pant KP, et al Computational techniques for human genome resequencing using mated gapped reads. J Comput Biol 2012;19:279-92.

16. Drmanac R, Sparks AB, Callow MJ, Halpern AL, Burns NL, Kermani BG, et al. Human genome sequencing using unchained base reads on self-assembling DNA nanoarrays. Science 2010;327:78-81.

17. Ohsumi TK, Borowsky ML. MolBioLib: a $\mathrm{C}++11$ framework for rapid development and deployment of bioinformatics tasks. Bioinformatics 2012;28: 2412-6.

18. Jabara HH, McDonald DR, Janssen E, Massaad MJ, Ramesh N, Borzutzky A, et al DOCK8 functions as an adaptor that links TLR-MyD88 signaling to B cell activation. Nat Immunol 2012;13:612-20.

19. Shearer WT, Rosenblatt HM, Gelman RS, Oyomopito R, Plaeger S, Stiehm ER, et al. Lymphocyte subsets in healthy children from birth through 18 years of age: the Pediatric AIDS Clinical Trials Group P1009 study. J Allergy Clin Immunol 2003;112:973-80.

20. Jolliff CR, Cost KM, Stivrins PC, Grossman PP, Nolte CR, Franco SM, et al. Reference intervals for serum $\operatorname{IgG}, \operatorname{Ig} \mathrm{A}, \operatorname{IgM}, \mathrm{C} 3$, and $\mathrm{C} 4$ as determined by rate nephelometry. Clin Chem 1982;28:126-8.

21. Zetterström O, Johansson SG. IgE concentrations measured by PRIST in serum of healthy adults and in patients with respiratory allergy. A diagnostic approach. Allergy 1981;36:537-47.

22. Kjellman NM, Johansson SG, Roth A. Serum IgE levels in healthy children quantified by a sandwich technique (PRIST*). Clin Exp Allergy 1976;6: 51-9.

23. Nal B, Carroll P, Mohr E, Verthuy C, Da Silva MI, Gayet O, et al. Coronin-1 expression in $\mathrm{T}$ lymphocytes: insights into protein function during $\mathrm{T}$ cell development and activation. Int Immunol 2004;16:231-40. 
24. Oku T, Itoh S, Okano M, Suzuki A, Suzuki K, Nakajin S, et al. Two regions responsible for the actin binding of p57, a mammalian coronin family actinbinding protein. Biol Pharm Bull 2003;26:409-16.

25. Rodal AA, Sokolova O, Robins DB, Daugherty KM, Hippenmeyer S, Riezman H, et al. Conformational changes in the Arp $2 / 3$ complex leading to actin nucleation. Nat Struct Mol Biol 2005;12:26-31.

26. Cai L, Holoweckyj N, Schaller MD, Bear JE. Phosphorylation of coronin 1B by protein kinase $\mathrm{C}$ regulates interaction with Arp2/3 and cell motility. J Biol Chem 2005;280:31913-23.

27. Ferrari G, Langen H, Naito M, Pieters J. A coat protein on phagosomes involved in the intracellular survival of mycobacteria. Cell 1999;97:435-47.

28. Grogan A, Reeves E, Keep N, Wientjes F, Totty NF, Burlingame AL, et al Cytosolic phox proteins interact with and regulate the assembly of coronin in neutrophils. J Cell Sci 1997;110:3071-81.

29. Ono S. Regulation of actin filament dynamics by actin depolymerizing factor/ cofilin and actin-interacting protein 1: new blades for twisted filaments. Biochemistry 2003;42:13363-70.
30. Brieher WM, Kueh HY, Ballif BA, Mitchison TJ. Rapid actin monomer-insensitive depolymerization of Listeria actin comet tails by cofilin, coronin, and Aip1. J Cell Biol 2006;175:315-24

31. Moulding DA, Blundell MP, Spiller DG, White MR, Cory GO, Calle Y, et al Unregulated actin polymerization by WASp causes defects of mitosis and cytokinesis in X-linked neutropenia. J Exp Med 2007;204:2213-24.

32. Tchang VS, Mekker A, Siegmund K, Karrer U, Pieters J. Diverging role for coronin 1 in antiviral CD4+ and CD8 + T cell responses. Mol Immunol 2013;56:683-92.

33. Zhang Q, Dove CG, Hor JL, Murdock HM, Strauss-Albee DM, Garcia JA, et al. DOCK8 regulates lymphocyte shape integrity for skin antiviral immunity. J Exp Med 2014;211:2549-66.

34. Dobbs K, Dominguez Conde C, Zhang SY, Parolini S, Audry M, Chou J, et al. Inherited DOCK2 Deficiency in Patients with Early-Onset Invasive Infections. N Engl J Med 2015;372:2409-22.

35. Kogkopoulou O, Tzakos E, Mavrothalassitis G, Baldari CT, Paliogianni F, Young HA, et al. Conditional up-regulation of IL-2 production by p38 MAPK inactivation is mediated by increased Erk1/2 activity. J Leukoc Biol 2006;79:1052-60. 


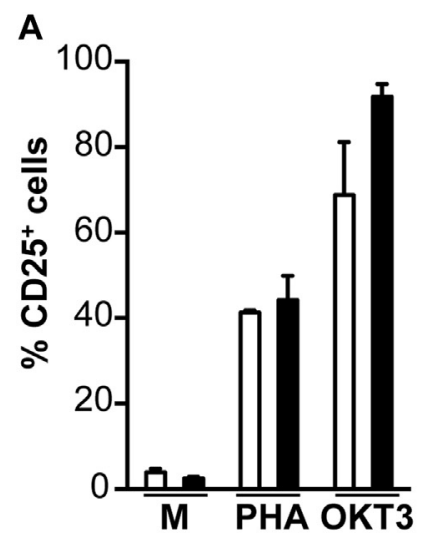

$\square$ Controls

- Patients
B

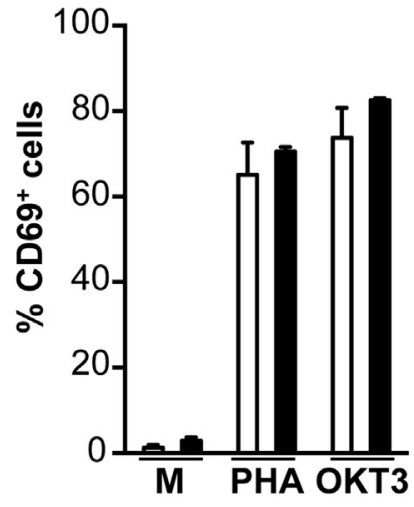

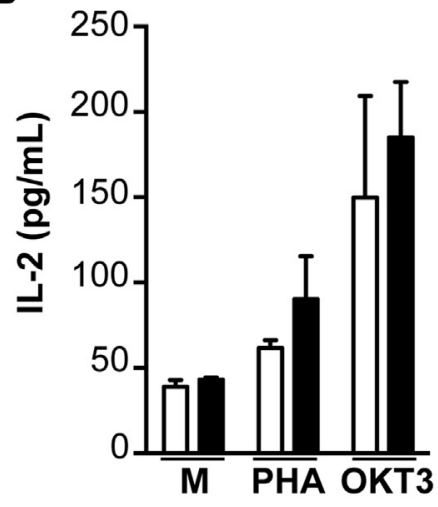

$\square$ Controls

- Patients

FIG E1. Expression of T-cell activation markers and IL-2 secretion after T-cell stimulation. A, Flow cytometric analysis of CD25 (left) and CD69 (right) on PBMCs after 2 days of stimulation with PHA or anti-CD3 antibody. $M$, Media. B, IL-2 secretion by PBMCs after 2 days of stimulation with PHA or anti-CD3. Graphs show means and SEs from 2 control subjects and 2 patients. By using the Student $t$ test, there was no significant difference between the patients and control subjects with regard to CD25 expression, CD69 expression, or IL-2 production under any of the culture conditions. 
TABLE E1. Nonsynonymous variants in coding and splice regions that reside within regions of homozygosity are homozygous in both patients, heterozygous in their mother, and not found in the dbSNP or 1000 Genomes databases

\begin{tabular}{llllll}
\hline Chromosome & Position & Region & $\begin{array}{c}\text { Nucleotide } \\
\text { change }\end{array}$ & $\begin{array}{c}\text { Amino } \\
\text { acid } \\
\text { change }\end{array}$ & Gene \\
\hline 16 & $28,508,515$ & Coding & $\mathrm{G}>\mathrm{A}$ & $\mathrm{G}>\mathrm{E}$ & $A P O B 48 R$ \\
16 & $28,916,375$ & Splice & $\mathrm{C}>\mathrm{G}$ & & $R A B E P 2$ \\
16 & $30,199,807$ & Coding & Insertion of C & See text & CORO1A \\
16 & $48,248,949$ & Splice & Insertion of A & & $A B C C 11$ \\
\hline
\end{tabular}

